\title{
KONTRIBUSI KUALITAS HIDUP TERHADAP SUCCESSSFULL AGING LANSIA
}

\author{
Shella Febrita Puteri Utomo ${ }^{1}$, Ahmad Gimmy Prathama Siswadi ${ }^{2}$, Aat Sriati ${ }^{3}$ \\ ${ }^{1)}$ Sekolah Tinggi Ilmu Kesehatan 'Aisyiyah Bandung \\ 2,3) Universitas Padjadjaran \\ shella.utomo@yahoo.com
}

\begin{abstract}
ABSTRAK
Penuaan merupakan suatu proses lansia pada tahap perkembangan sehingga lansia mengalami penurunan pada fungsi fisik, psikologis, dan sosial. Perubahan juga mengharuskan lansia untuk mampu beradaptasi atas kemunduran yang dialami. Kualitas hidup merupakan salah satu hal yang dibutuhkan untuk mencapai successful aging. Successful aging merupakan kondisi lansia baik secara fisik, psikologis, sosial maupun proses adaptasi untuk mengoptimalkan kemampuan yang dimiliki akibat proses penuaan. Tujuan penelitian ini adalah mengidentifikasi kontribusi kualitas hidup terhadap successful aging. Metode penelitian ini kuantitatif dengan pendekatan cross sectional. Populasi penelitian yaitu lansia yang tinggal di BPSTW Ciparay Provinsi Jawa Barat. Teknik pengambilan sample purposive sampling dengan jumlah sampel sebanyak 71 orang. Instrumen penelitian menggunakan OPQOL 13 dan SAS-14. Analisis data dengan uji korelasi menggunakan uji chi square untuk menganalisis kontribusi kualitas hidup terhadap successful aging. Hasil penelitian menunjukkan jumlah successsful aging dalam kategori tinggi sebanyak 28 responden dan kategori rendah sebanyak 43 responden. Kualitas hidup menunjukkan adanya hubungan yang signifikan terhadap successful aging $(\mathrm{p}<0,05)$. Kesimpulan penelitian ini adalah kualitas hidup yang baik dapat berkontribusi bagi lansia untuk mencapai kondisi successful aging, dan dimensi yang paling berkontribusi pada kualitas hidup yaitu aspek materi, kepuasan hidup, sosial dan psikologis. Adapun, dimensi yang memengaruhi tidak tercapainya successful aging yaitu kesehatan, kemandirian dan hubungan sosial.
\end{abstract}

Kata kunci : kualitas hidup, lansia, panti wreda, successful aging

\section{Abstract}

Aging is a process of development stages in the elderly where they experience a decline in physical, psychological, and social functions. The elderly with the quality of life are those who have the ability to adapt to the changing conditions. The quality of life is one of the things needed to achieve the successful aging. Elderly who have the ability of the optimal adaptation process to changes in the aging process in physical, psychological, and social functions, they achieve successful aging. The purpose of this study was to identify the contribution of quality of life on successful aging in the elderly. A cross-sectional study was conducted involving a sample with a consecutive sampling method in 71 elderly subjects who stay in BPSTW Ciparay, West Java Province. The research instrument used OPQOL 13, and SAS-14. Through a correlation test analysis with chi squre used to identify the contribution of quality on successful aging on elderly. The results showed a high level of successful aging by 28 respondents and a low level of successful aging by 43 respondents. The quality of life showed a significant relationship to successful aging $(p<0.05)$. The elderly's good quality of life can contribute to achieving successful aging. In addition, the dimensions that most contribute to the quality of life were material aspects, life satisfaction, social and psychological. While the dimensions that did not influence the successful aging were health, independence and social relations.

Keywords: elderly, elder care community, quality of life, successful aging 


\section{PENDAHULUAN}

Lanjut usia (Lansia) merupakan kumpulan kelompok yang mengalami peningkatan jumlah populasi setiap tahunnya (Badan Statistik Pusat, 2019). Tercatat peningkatan lansia pada tahun 2010 sebanyak 7,18\%, tahun 2011 menjadi 9,12\% dan di tahun 2015 meningkat menjadi 9,74\% (Badan Statistik Pusat, 2014). Bedasarkan data tahun 2019 juga terlihat pertumbuhan lansia sebanyak 2,9\% setiap tahun, berbeda dengan pertumbuhan total penduduk yang hanya meningkat sebanyak $0,5 \%$ per tahun. Dengan kondisi ini maka menjadikan Indonesia sebagai aging structured population (Veronica, 2017).

Peningkatan jumlah lansia menjadikan suatu tantangan baru bagi individu ataupun pemerintah akibat dari proses penuaan dan perubahanyangterjadi(Reker,G.T., \&Wong, 1985). Penuaan merupakan suatu proses pertumbuhan tahap akhir kehidupan dan sangat berbeda dengan penyakit. Sehingga seorang lansia akan mengalami penurunan pada fungsi fisik, sosial, dan psikologis dan berdampak pada keterbatasan aktivitas hal ini dinamakan ussuall aging (Rowe, J. W., \& Kahn, 1997; Whitbourne, 2005). Kondisi ini menjadikan lansia memiliki pemikiran negatif pada diri yang dapat mempengaruhi rasa kepercayaan diri hingga mengalami masalah harga diri rendah (Bowling, A., Hankins, M., Windle, G., Bilotta, C., \& Grant, 2013). Selain itu ketidak mampuan lansia dalam beradaptasi atas perubahan yang dialami akan menjadikan lansia mengalami masalah psikososial (Chalisen, 2014; Kartinah \& Sudaryanto, 2008).

Berdasarkan teori perkembangan Erikson, seharusnya lansia memiliki kemampuan untuk

Menghadapai masalah dan mengendalikan perubahan yang terjadi sehingga mengantarkan lansia menjadi sejahtera secara psikologis (Reker, 2009). Kondisi ini menjadi salah satu faktor yang dapat mendukung tercapainya successful aging (Jennifer Reichstadt, Geetika Sengupta, Colin A Deep, LawrenceA. Palinkas, 2010). Namun berdasarkan hasil penelitian masih banyak lansia yang merasa tidak bahagia di masa tuanya, lansia memiliki keterbatasan baik secara fisik dan psikologis (McCabe \& O'Connor, 2013). Hal ini mempengaruhi lansia atas kehidupannya dan menjadikan lansia tidak mencapai successful aging.

Successful aging merupakan kondisi dimana lansia merasa baik ditunjukan dengan tidak adanya penyakit fisik, memiliki fungsi fisik dan kognitif yang baik, aktif dalam kehidupan (Rowe, J. W., \& Kahn, 1997). Selain itu successful aging adalah kondisi dimana lansia merasa bahagia, memiliki pemikiran positif dan sejahtera (Whitbourne, 2005). Penelitian lain mengungkapkan bahwa successful aging adalah rasa kepuasan lansia terhadap kehidupannya dimasa lalu (Oh, S. H., Kim, D. K., Lee, S. U., Jung, S. H., \& Lee, 2017).

Berdasarkan hasil studi pendahuluan yang dilakukan di BPSTW Ciparay Provinsi Jawa Barat. Jumlah populasi lansia sebanyak 150. Dengan metode wawancara dan observasi didaptkan beberapa lansia, merasa tidak berharga karena merasa di acuhkan oleh keluarga. Selain itu ada pula lansia yang merasa memiliki keterbatasan dalam beraktivitas dan merasa sedih jika tidak memiliki penghasilan sendiri untuk memenuhi kebutuhan sehari -hari dan berbagi dengan anak dan keluarga.

Berdasarkan masalah tersebut maka peneliti mengganggap penting untuk melakukan penelitian mengenai kontribusi kualitas hidup terhadap successful aging lansia di BPSTW Ciparay Provinsi Jawa Barat.

\section{METODOLOGI}

Penelitian ini merupakan penelitian kuantitatif dengan desain penelitian cross sectional. Variabel bebas adalah kualitas hidup dan variabel terikat yaitu succesful aging. Populasi dalam penelitian ini yaitu lansia yang tinggal di 
BPSTW Ciparay Provinsi Jawa Barat berjumlah 150 lansia dengan menggunakan teknik purposive sampling dengan ketentuan kriteria inklusi (1. Memiliki nilai MMSE baik-sedang, 2. Usia 6085 tahun, 3. Kooperatif), dan kriteria eksklusi (1. Berada di ruang rawat khusus, 2. Mengalami gangguan pendengaran atau pengelihatan, 3 . mengalami masalah sakit fisik berat). Sehingga didapatkan sampel sebanyak 71 responden.

Kuesioner yang digunakan dalam penelitian terdiri dari kuesioner data demografi, dan kuisioner baku kualitas hidup yaitu OPQOL (Older People Quality of Life-Brief 13) dan SAS (Successful Aging Scale - 14) (Bilotta et al., 2011). Kuesioner telah dinyatakan valid karena memiliki nilai $r>0,3$, dan dinyatakan reliabel karena memiliki nilai alpha $>0,06$ (Bilotta et al., 2011; Reker, G. T., \& Wong, 1997).

Analisis data dalam penelitian ini, dengan analisis univariat untuk menggambarkan karakteristik data demografi responden, dan analisis bivariat untuk mengetahui kontribusi antara kualitas hidup dan successful aging. Uji normalitas data menggunakan Kolmogrov-smirnov untuk melihat normalitas distribusi data. Karena data tidak terdistribusi normal maka dalam penelitian ini menggunakan nilai median dengan uji chisquare.

HASIL

\section{A. Karakteristik Demografi Responden}

Tabel 1. Karakteristik Demografi Responden

\begin{tabular}{lcc}
\multicolumn{1}{c}{$(\mathbf{n}=\mathbf{7 1})$} & \\
\hline \multicolumn{1}{c}{ Karakteristik } & f & \% \\
\hline Usia & & \\
$60-74$ & 39 & 54,9 \\
$75-90$ & 32 & 45,1 \\
Jenis Kelamin & & \\
Laki-laki & 31 & 43,7 \\
Perempuan & 40 & 56,3 \\
Lama Tinggal di Panti & & \\
$<1$ Tahun & 24 & 33,8 \\
\hline
\end{tabular}

\begin{tabular}{lcc}
\hline \multicolumn{1}{c}{ Karakteristik } & f & \% \\
\hline 1-5 Tahun & 25 & 35,2 \\
>5-10 Tahun & 17 & 23,9 \\
>10 Tahun & 5 & 7,0 \\
Penghasilan & & \\
Ada & 27 & 38,0 \\
Tidak Ada & 44 & 62,0 \\
\hline
\end{tabular}

Berdasarkan tabel 1 diketahui jumlah responden terbanyak pada kelompok elder dimana rentang usia 60-74 tahun sebanyak 54,9\% (WHO, 2009). Didominasi oleh perempuan 56,4\% dengan status pernikahan janda 47,9\%.

Tabel 2. Pendidikan dan Status Pernikahan

\begin{tabular}{lcc}
\multicolumn{2}{c}{$(\mathbf{n}=\mathbf{7 1})$} & \\
\hline \multicolumn{1}{c}{ Karakteristik } & f & \% \\
\hline Pendidikan Terakhir & & \\
Tidak Sekolah & 16 & 22,5 \\
SD & 28 & 39,4 \\
SMP & 16 & 22,5 \\
SMA & 9 & 12,7 \\
Perguruan Tinggi & 2 & 2,8 \\
Status Pernikahan & & \\
Menikah & 7 & 9,9 \\
Tidak Menikah & 3 & 4,2 \\
Janda & 34 & 47,9 \\
Duda & 27 & 38,0 \\
\hline
\end{tabular}

Berdasarkan tabel 2, tingkat pendidikan responden sebagian besar hanya mengenyam hingga tingkat SD $(39,4 \%)$. Lama responden tinggal di panti sekitar 1-5 tahun sebanyak $35,2 \%$. Sebagian besar responden mengaku tidak memiliki penghasilan sebanyak $62 \%$.

\section{B. Gambaran Kualitas Hidup}

Tabel 3. Gambaran Kualitas Hidup Lansia $(n=71)$

\begin{tabular}{llcc}
\hline \multicolumn{1}{c}{ Variabel } & \multicolumn{1}{c}{ Hasil } & f & \% \\
\hline Kualitas & Baik & 34 & 47,88 \\
Hidup & Tidak Baik & 37 & 52,11 \\
\hline
\end{tabular}

Berdasarkan tabel 3 dapat diketahui bahwa lebih dari 50\%, sebanyak 37 lansia memiliki kualitas hidup yang tidak baik. 
C. Gambaran Succesful Aging

Tabel 4. Gambaran Successful Aging Lansia $(\mathrm{n}=71)$

\begin{tabular}{llcc}
\hline \multicolumn{1}{c}{ Variabel } & Hasil & f & \% \\
\hline Successful & Tinggi & 28 & 39,43 \\
aging & Rendah & 43 & 60,56 \\
\hline
\end{tabular}

Berdasarkan tabel 4 diketahui successful aging lansia dengan jumlah persentase sebanyak 60,56\% menunjukan hasil successful aging rendah.
D. Kontribusi Kualitas Hidup dan Successful Aging

Tabel 5. Kontribusi Kualitas Hidup terhadap Successful Aging (n=71)

\begin{tabular}{|c|c|c|c|c|c|}
\hline \multirow{2}{*}{ Variabel } & \multicolumn{4}{|c|}{ Successful Aging } & \multirow{2}{*}{ Nilai $p$} \\
\hline & Tinggi & $\%$ & Rendah & $\%$ & \\
\hline \multicolumn{6}{|l|}{ Kualitas Hidup } \\
\hline Baik & 20 & 71,4 & 14 & 32,6 & $0,001^{*}$ \\
\hline Tidak Baik & 8 & 28,6 & 29 & 67,4 & \\
\hline
\end{tabular}

Ket:, $C$ CI=Confidence Interval, analisis menggunakan chi square test, ${ }^{*}$ bermakna $\mathrm{p}<0,05$

Berdasarkan tabel 5 menunjukkan adanya hubungan yang signifikan antara kualitas hidup dan successful aging ditunjukan dengan nilai $\mathrm{p}$ sebesar 0,001 .

Tabel 6. Kualitas Hidup Lansia Berdasarkan Dimensi $(n=71)$

\begin{tabular}{|c|c|c|c|c|c|c|c|}
\hline & \multirow{2}{*}{ Dimensi } & \multicolumn{5}{|c|}{ Successful Aging } & \multirow{2}{*}{ Nilai p } \\
\hline & & $\mathbf{n}$ & Tinggi & $\%$ & Rendah & $\%$ & \\
\hline \multirow[t]{2}{*}{ Kepuasan Hidup } & Baik (>13) & 33 & 22 & 66,7 & 11 & 33,3 & $<0,001$ \\
\hline & Tidak Baik $(\leq 13)$ & 38 & 6 & 15,8 & 32 & 84,2 & \\
\hline \multirow[t]{2}{*}{ Kesehatan } & Baik (>8) & 27 & 14 & 51,9 & 13 & 48,1 & 0,094 \\
\hline & Tidak Baik $(\leq 8)$ & 44 & 14 & 31,8 & 30 & 68,2 & \\
\hline \multirow[t]{2}{*}{ Kegiatan Sosial } & Baik (>4) & 20 & 10 & 50,0 & 10 & 50,0 & 0,254 \\
\hline & Tidak Baik $(\leq 4)$ & 51 & 18 & 35,3 & 33 & 64,7 & \\
\hline \multirow[t]{2}{*}{ Kemandirian } & Baik (>9) & 25 & 12 & 48,0 & 13 & 52,0 & 0,276 \\
\hline & Tidak Baik $(\leq 9)$ & 46 & 16 & 34,8 & 30 & 65,2 & \\
\hline \multirow[t]{2}{*}{ Sosial } & Baik (>9) & 32 & 19 & 59,4 & 13 & 40,6 & 0,002 \\
\hline & Tidak Baik $(\leq 9)$ & 39 & 9 & 23,1 & 30 & 76,9 & \\
\hline \multirow[t]{2}{*}{ Psikologis } & Baik (>8) & 31 & 18 & 58,1 & 13 & 41,9 & 0,005 \\
\hline & Tidak Baik $(\leq 8)$ & 40 & 10 & 25,0 & 30 & 75,0 & \\
\hline \multirow[t]{2}{*}{ Materi } & Baik (>2) & 34 & 10 & 29,4 & 24 & 70,6 & 0,098 \\
\hline & Tidak Baik $(\leq 2)$ & 37 & 18 & 48,6 & 19 & 51,4 & \\
\hline
\end{tabular}

Ket: Analisis uji chi square, ${ }^{*} \mathrm{p}<0,05$

Berdasarkan tabel 6 diketahui bahwa pada kualitas hidup baik dimensi yang memberikan kontribusi terhadap successful aging tinggi secara bermakna yaitu kepuasan hidup sebanyak $66,7 \%$, sosial (bertetangga dan tempat tinggal) 59,4\%, dan psikologis lansia 58,1\%.

\section{PEMBAHASAN}

\section{A. Karakteristik Demografi Responden}

Berdasarkan karakteristik responden lansia yang tinggal di BPSTW Ciparay Provinsi Jawa Barat, diketahui usianya responden rata rata usia 60-74 tahun. Hampir seluruh responden 
berjenis kelamin perempuan. Seiring berjalanya waktu penambahan usia dan angka harapan hidup jika tidak diperhatikan secara serius oleh individu dan pihak panti akan menambah hambatan dengan penurunan fungsi fisik dan kognitifnya serta munculnya keluhan penyakit degeneratif seperti penyakit jantung, osteoporosis, hipertensi, DM dan kanker (Noorkasiani, 2009; Tanaka, 2013). Perubahan pada fisik dapat menjadi salah satu faktor resiko lansia tidak dapat mencapai kualitas hidup yang baik, karena lansia mengalami keterbatasan dalam beraktivitas sehingga lansia merasa putus asa (Anis, 2012).

Melihat lama tinggal di panti, sebagian besar lansia sudah tinggal di panti lebih dari 5 tahun. Hal ini menjadikan lansia tidak memiliki pekerjaan dan menjadi tidak mandiri secara finansial. Berdasarkan hasil penelitian salah satu faktor yang menyebabkan seorang lansia tidak memiliki pekerjaan dikarenakan oleh rendahnya pendidikan, sesuai data mayoritas pendidikan lansia hanya di tingkat SD (Lei, X., Hu, Y., Mcardle, J. J., Smith, J. P. dan Zhao, 2011).

Hasil penelitian menunjukan responden di BPSTW Ciparay memiliki nilai kualitas hidup paling banyak menunjukan hasil yang tidak baik sebanyak 52,1\% dan kualitas hidup baik sebanyak 47,9\%. Dapat disimpulkan hasil penelitian ini menunjukan kualitas hidup lansia di BPSTW Ciparay belum tercapai secara optimal. Sejalan dengan penelitian yang dilakukan oleh Putri, 2013 mengatakan bahwa lansia akan memiliki kulitas lebih baik jika tinggal bersama keluarga dibandingkan tinggal di panti. Lansia memiliki rasa percaya diri dan kemampuan untuk memenuhi kebutuhan ekonomi dan masih bisa berinteraksi bersama keluarga (Putri, Suci Tuty, 2013). Kualitas hidup merupakan persepsi yang bersifat subjektif terhadap kehidupan pada masa tua meliputi kesehatan, kecukupan, perasan berguna, partisipasi dalam kehidupan sosial dan status ekonomi (Bowling, A., Hankins,
M., Windle, G., Bilotta, C., \& Grant, 2013; Netuveli, Gopalakrishnan \& Blane, 2008)

Berdasarkan hasil analisa dimensi kualitas hidup yang menunjukan tidak baik yaitu dimensi kesehatan, kemandirian, dan hubungan sosial. Hasil observasi yang dilakukan peneliti, ditemukan tingkat kesehatan lansia di BPSTW Ciparay belum optimal karena sebagian kecil lansia sebanyak 43 yang mengalami sakit fisik berat dan gangguan mental sehingga memerlukan perawatan khusus. Namun pada uji ststistik dimensi kesehatan menjadi salah satu dimensi terendah sebanyak $62 \%$ menunjukan lansia berada pada kondisi tidak baik. Berdasarkan kajian literatur kesehatan pada kualitas hidup menggambarkan kondisi fisik yang kuat pada lansia, sehingga lansia dapat melakukan aktivitas sehari-hari tanpa mengalami hambatan (Bowling, 2012; Li, 2014). Selain itu penilaian pribadi pada lansia merasa sehat sehingga mampu untuk beraktifitas juga merupakan aspek yang terdapat dalam dimensi kesehatan.

Menilai kesehatan pada dimensi kualitas hidup lansia tidak hanya terlihat secara fisik, namun faktor resiko juga dapat mempengaruhi kondisi kesehatan lansia dimasa yang akan datang merupakan bagian dari kesehatan (Rowe, J. W., \& Kahn, 1997). Selain itu kesehatan merupakan kondisi individu yang baik secara fisi dan psikologis (Jennifer Reichstadt, Geetika Sengupta , Colin A Deep, LawrenceA. Palinkas, 2010). Kesehatan berhubungan dengan kondisi mental dikaitkan dengan keberfungsian status fungsional, adanya dukungan sosial dan kondisi ekonomi lansia (Kartinah \& Sudaryanto, 2008). Penilaian kesehatan pada setiap individu bersifat subjektif sehingga penilaian kondisi kesehatan setiap individu berbeda-beda dan dapat berpengaruh pada perubahan emosional. Kesehatan merupakan salah satu dimensi yang berperan penting dalam menggambarkan kualitas hidup karena lansia dapat menikmati hal-hal penting yang terjadi dalam hidupnya (Noorkasiani, 2009). 
Dimensi terendah selanjutnya yaitu kemandirian lansia, pada dimensi ini dijelaskan bagaimana lansia memiliki perasaan senang dengan apa yang dikerjakan saat ini, dan lansia juga merasa cukup baik dan sehat untuk dapat melakukan aktivitasnya sehari-hari tanpa mendapatkan bantuan apapun (Bowling, Ann \& Liffe, 2011; Bowling, 2012). Kemandirian lansia di BPSTW Ciparay menujukan hasil yang rendah dikarenakan banyak lansia merasa terbatasi dengan rangkaian kegiatan yang dijadwalkan oleh pihak BPSTW. Selain itu lansia yang ikut serta dalam rangkaian kegiatan di BPSTW merasa kurang senang karena sifat kegiatan yang berulang dan adanya paksaan. Menurut penelitian keterpaksaan lansia dalam melakukan kegiatan merupakan suatu penghambat dalam pencapain tingkat kemandirian secara pribadi di masa tua, serta kurangnya keterlibatan lansia dalam melakukan aktifitas sehari hari yang dilakukan secara rutin dan dalam waktu yang lama dapat mempengaruhi pencapaian kualitas hidup yang baik (Jennifer Reichstadt M.S, Geetika Sengupta M.D, Colin A Deep Ph.D, LawrenceA. Palinkas Ph.D, 2010).

Dimensi terakhir yang menunjukan kualitas hidup tidak baik yaitu dimensi hubungan sosial. Hubungan sosial terlihat pada waktu dan kegiatan yang dilakukan lansia (Ita, 2017). Aspek yang terdapat pada dimensi hubungan sosial yaitu adanya keterkaitannya keluarga, tetangga dan teman (Gabriel, Z \& Bowling, 2004). Pada penelitian ini berdasarkan hasil wawancara, ditemukan lansia mengaku merasa tidak memiliki orang terdekat di panti dan intensitas kunjungan dari keluarga terlogong jarang bahkan tidak pernah. Menurut Bilotta, (2011) dukungan sosial dari pasangan hidup, keluarga (anak dan cucu), serta lingkungan merupakan faktor penting bagi lansia untuk mencapai kualitas hidup baik (Bilotta et al., 2011; Bowling, A., Hankins, M., Windle, G., Bilotta, C., \& Grant, 2013). Selain itu penelitian di Indonesia menunjukan bahwa kualiatas hidup lebih baik pada lansia yang tinggal bersama keluarga dibandingkan dengan lansia yang tinggal di Panti werdha. Hal ini dikarenakan lansia yang tinggal bersama keluarga tidak merasa kesepian, merasa di hargai tidak terasingkan, dekat dengan anak dan cucu. Selain itu lansia juga dapat memenuhi kebutuhan ekonomi secara mandiri dan tidak ada masih bisa tetap aktif melakukan aktivitas sosial di lingkungan (Putra, 2009; Putri, Suci Tuty, 2013). Hubungan sosial dapat mendukung lansia untuk mencapai kualitas hidup yang aktif, hal ini dipengaruhi dengan munculnya sikap positif yang ditunjukan lansia salah satunya memiliki kemampuan adaptasi sehingga lansia dapat bertahan atas berbagai hal yang dihadapi (Bowling, 2012).

Kualitas hidup baik berdasarkan dimensi pada penelitian ini menunjukan empat dimensi tertinggi yaitu dimensi materi dengan jumlah 47,9 \% .Dimensi kepuasan hidup sebanyak 46,5\%, dimensi sosial (rumah dan bertetangga) sebanyak $45,1 \%$ dan terakhir dimensi psikologis $43,7 \%$. Dimensi materi dalam penelitian ini menunjukan dimensi tertinggi untuk menggambarkan kualitas hidup yang baik pada lansia di BPSTW Ciparay. Pernyataan yang diungkapkan lansia untuk menggambarkan dimensi ini yaitu lansia mengakui mampu untuk memenuhi kebutuhan sehari-hari secara finansial selama tinggal di BPSTW. Namun berdasarkan karakteristik responden ditemukan lansia yang tinggal di BPSTW tidak memiliki pekerjaan dan penghasilan sebanyak $62 \%$, namun beberapa lansia mendapatkan penghasilan di panti dengan menjual jasa antar lansia, sebagai buruh cuci/ setrika baju. Selain itu ada beberapa lansia yang mendapatkan uang dari keluarga.

Menurut penelitian yang dilakukan Bilotta et al., (2011) materi pada lansia tidak ternilai atas berapa jumlah finansial yang dimiliki, banyak lansia yang memiliki pendapatan lebih rendah dibandingkan masa di waktu muda namun lansia 
memiliki rasa kepuasan finansial. Kepuasan lansia terhadap finansial terlihat dari pencapaian lansia masih mampu dan produktif untuk mencari uang secara mandiri tanpa memperhitungkan jumlah yang diperoleh (Gabriel, Z \& Bowling, 2004).

Kesadaran lansia atas keterbatasan yang dimiliki merupakan suatu proses penuaan serta keyakinan atas kesempatan yang dimiliki di masa tua dapat mendukung lansia untuk mencapai tingkat kepuasan tinggi pada aspek ekonomi. Kemampuan adaptasi adaptif yang ditunjukan lansia pada dimensi ini yaitu lansia mampu menyesuaikan kebutuhan untuk mempertahankan keuangan dan tingkat kesejahteraan (Browning, Colette \& Thomas, 2013). Budaya juga mampengaruhi lansia dalam pencapaian dimensi materi, penelitian yang dilakukan di Provinsi Jawa tengah, dengan keyakinan menerima setiap pemberian, sehingga menunjukkan karakter lansia tidak mau mengeluh atau mengekspresikan atas kekuranganya terhadap masalah finansial kepada anak dan saudara, sehingga lansia memilih menerima dan mensyukuri atas apa yang di terimanya (Ita, 2017; Jennifer Reichstadt M.S, Geetika Sengupta M.D, Colin A Deep Ph.D, LawrenceA. Palinkas Ph.D, 2010; Putra, 2009).

Dimensi kedua yaitu kepuasan hidup/ keseluruhan hidup pada penelitian ini sebanyak 46,5\% responden menunjukan kepuasan hidup baik. Dimensi ini membahas kepuasan lansia atas kehidupannnya saat ini, kepuasan atas pengalaman hidup yang sudah dilaluinya, merasa bahagia di setiap waktu, dan mampu mengerakan hal positif seperti membuat rencana untuk masa depan dan menghindari hal-hal yang dapat menyebabkan resiko buruk terhadap diri (Bowling, 2012).

Dimensi ketiga yaitu sosial pada kualitas hidup lansia, sosial membahas tempat tinggal (rumah) dan hubungan bertetangga (Bowling, A., Hankins, M., Windle, G., Bilotta, C., \& Grant, 2013). Berdasarkan hasil observasi fasilitas dan lingkungan di BPSTW Ciparay, ditemukan faktor yang mendukung kualitas hidup baik pada lansia di BPSTW Ciparay yaitu kelayakan tempat tinggal dan lingkungan dengan desain ramah lansia, serta kelengkapan sarana dan prasarana bagi lansia. Sesuai dengan penelitian sebelumnya yang menyatakan bahwa salah satu pengukuran kualitas hidup baik di panti yaitu kondisi tempat tinggal yang aman, nyaman, memiliki hubungan bertetangga yang hangat dan harmonis serta tersedianya fasilitas umum seperti tempat ibadah, klinik, dan sarana berolah raga (Browning, Colette \& Thomas, 2013). Lingkungan baik dapat memberikan perasaan nyaman, aman, tenang dalam hal ini lingkungan memberikan pengaruh baik dalam pencapaian kualitas hidup baik (McCabe \& O'Connor, 2013).

Kondisi bertetangga dengan damai dapat meningkatkan interaksi sosial dan lingkungan yang menumbuhkan rasa kepedulian antara lansia, dan memberi pengaruh positif berupa dukungan sosial teman yang dapat meningkatkan kualitas hidup berdasarkan dimensi kegiatan sosial, kemandirian, dan kepuasan hidup (Bowling, 2012; Jennifer Reichstadt M.S, Geetika Sengupta M.D, Colin A Deep Ph.D, LawrenceA. Palinkas Ph.D, 2010). Menurut penelitian interaksi sosial yang terjalin dan berlangsung lama serta keterlibatan lansia dalam berpartisipasi pada kegiatan di panti werda dapat mempengaruhi peningkatan kualitas hidup lansia di panti werda (Kartinah \& Sudaryanto, 2008).

Dimensi terakhir yang menunjukan kualitas hidup baik di BPSTW Ciparay adalah psikologis. Dimensi ini berhubungan dengan kesejahteraan psikologis dimana terdapat aspek kepuasan hidup, kepercayaan diri, tujuan hidup, kontrol kehidupan dan persepsi mengenai penampilan (Bowling, 2012; Ryff, 1989). Pernyataan yang menggambarkan dimensi ini yaitu memiliki rasa lebih beruntung dibandingkan dengan orang lain sehingga menilai bahwa kehidupan yang dialami adalah suatu anugrah 
terbaik (Raras Anggun Atika Candra, Eva Rahayu, 2018). Proses penuaan yang mengakibatkan terjadinya penurunan pada lansia dapat menjadi penghambat bagi lansia untuk melakukan aktivitas, namun penelitian menemukan lansia dengan psikologis baik pada kualias hidup dapat mencari solusi untuk melakukan kegiatan lainnya secara posif dan tetap bersemangat (Browning, Colette \& Thomas, 2013).

\section{B. Kontribusi Kualitas Hidup Lansia terhadap Succcessful Aging}

Hasil analisa untuk melihat kontribusi kualitas hidup terhadap successful aging lansia dengan menggunakan uji Chi Square menunjukan nilai $p=0,001$ yang berarti nilai $p<0,05$ sehingga bermakna terdapat hubungan yang signifikan antara kualitas hidup dan successful aging pada lansia di BPSTW Ciparay Provinsi Jawa Barat, sehingga menunjukan adanya kontibusi kualitas hidup terhadap successful aging.

Keseluruhan hidup berkontribusi terhadap successful aging karena lansia memiliki perasaan menerima atas kondisinya saat ini, baik perubahan pada fisik, psikologis dan sosialnya. Selain itu dimensi ini juga menjelaskan bagaimana lansia merasa senang dan bahagia atas apa yang dicapainya serta kemampuan dalam beradaptasi sehingga mampu melanjutkan kehidupan berdasarkan pengalaman masa lalu merupakan bentuk dari adaptasi adaptif lansia (Atchley, 1989).

Kesehatan berkontribusi terhadap successful aging bukan hanya terlihat dari segi fisik yang baik, namun kesehatan dalam dimensi ini menggambarkan kesehatan yang utuh secara fisik dan mental pada lansia sehingga menjadikan lansia mampu melakukan hal yang diingingkan denga baik (Gabriel, Z \& Bowling, 2004). Selain itu kesehatan dapat mempengaruhi kualitas hidup berhubungan dengan keadaan emosional lansia dimana lansia mampu untuk melakukan aktivitasnya sehingga lansia terhindar dari rasa putus asa (Bilotta et al., 2011).

Dimensi sosial pada kualitas hidup yang berkontribusi terhadap successful aging merupakan gambaran lansia merasa nyaman terhadap lingkungan tempat tinggal, dalam dimensi ini meliputi aktivitas bertetangga yang baik dan ramah. Kekuatan pada dimensi ini dapat memberiak dampak positif pada lansia, selain itu dimensi ini mengurangi keadaan stress akibat dari pengalaman kehilangan keluarga, pasangan hidup, peran dan perubahan lingkungan tempat tinggal. Dimensi sosial juga mencegah terjadinya dampak negatif atas perubahan penuaan yang menjadikan lansia mengalami isolasi sosial hingga peningkatan depresi (Li, 2014; Oh, S. H., Kim, D. K., Lee, S. U., Jung, S. H., \& Lee, 2017).

Psikologis menggambarkan bagaimana kehidupan serta aktivitas lansia yang dipengaruhi oleh pandangan psikologis (Putra, 2009). Pada dimensi ini terlihat cara pandang lansia dalam melihat sisi baik atas kehidupannya, seperti dalam pernyataan "saya menerima kehidupan saat ini, merasa beruntung dibandingkan dengan orang lain, merasa senang dengan kehidupan saat ini dan bahagia (Bowling, A., Hankins, M., Windle, G., Bilotta, C., \& Grant, 2013; Bowling, 2012).

Penelitian lain yang dilakukan di China menunjukkan successful aging lansia berdasarkan kualitas hidup baik dapat terlihat berdasarkan lansia memiliki umur panjang dengan keadaan yang baik dan sehat pada kondisi fisik dan mental (Reker, G. T., \& Wong, 1997). Kualitas hidup baik juga berhubungan dengan bagaimana lansia beraktivitas dan masih terlibat aktif pada kehidupan dan kegiatan sosial yang sudah dijalani dalam waktu lama (Netuveli, Gopalakrishnan \& Blane, 2008). Selain itu lansia yang memiliki fungsi kognitif dan fisik baik, dan memiliki penilaian positif atas dirinya memberikan kontribusi untuk menjadi successful aging berkaitan dengan dimensi fisik (McCabe \& O'Connor, 2013). Menemukan urutan hubungan tertinggi pada setiap dimensi 
yang berkontribusi terhadap successful aging yaitu kegiatan sosial, psikologis, dan dimensi fisik.

Berbeda dengan penelitian di atas, pada penelitian ini ditemukan urutan dimensi yang paling berkontribusi terhadap pencapaian successful aging yaitu kepuasan hidup, sosial dan psikologis. Menurut penelitian upaya yang dapat dilakukan untuk mencapai kepuasan hidup pada lansia dengan membangun rasa optimis dengan memiliki rancangan kegiatan yang akan dilakukan, hal ini dapat membantu lansia untuk kembali bersemangat (Oh, S. H., Kim, D. K., Lee, S. U., Jung, S. H., \& Lee, 2017). Upaya lain dengan melakukan kegiatan yang disenangi tanpa adanya paksaan untuk melakukannya kegiatan tersebut, serta kemampuan lansia dalam menikmati setiap rangkaian kegiatan tersebut (Kimm, Heejin. Jae woong sull, 2012).

\section{SIMPULAN DAN SARAN}

Hasil penelitian menunjukan usia lansia di BPSTW Ciparay paling banyak pada rentang 60-74 tahun, dengan mayoritas jenis kelamin perempuan. Dengan lama tinggal 1-5 tahun. Tidak memili penhasilan mandiri, dengan status pernikahan janda dan duda.

Kontribusi kualitas hidup dengan successful aging pada lansia di BPSTW Ciparay Provinsi Jawa Barat menunjukkan adanya hubungan yang signifikan. Berdasarkan dimensi kualitas hidup yang paling berkontribusi mendukung pencapaian successful aging yaitu aspek materi, kepuasan hidup, sosial dan psikologis.

Perawat diharapkan dapat mengembangkan asuhan keperawatan dengan tujuan untuk meningkatkan kualitas hidup lansia dapat melakukan upaya promotif dan preventif terkait successful aging dengan pendekatan fisik yaitu memotivasi aktivitas berolahraga, dan memfasilitasi gaya hidup sehat. Pendekatan psikologis dapat diterapkan dengan menjadi pendengar yang baik dan sebagai sahabat yang dapat di percaya sehingga mampu mendengarkan keluh kesah dan rahasia lansia dengan perasaan tulus, sabar, dan simpatik. Pendekatan terakhir pada aspek sosial dengan menciptakan hubungan sosial yang baik dengan cara melakukan perkumpulan terjadwal untuk melakukan kegiatan bertukar pikiran.

Bagi peneliti selanjutnya diharapkan dapat mengembangkan faktor-faktor yang memengaruhi pada setiap dimensi yaitu kepuasan hidup, sosial dan psikologis sehingga akan lebih komprehensif mendapaikan hasil mengenai successful aging.

\section{DAFTAR PUSTAKA}

Anis, R. (2012). Kualitas Hidup Lanjut Usia. Jurnal Keperawatan, (ISSN 2086-3071).

Atchley, R. (1989). A Continuity Theory of Normal Aging. The Gerontological. https://doi. org/1 0.1093/geront/29.2.183

Badan Statistik Pusat. (2014). Statistik Penduduk Lanjut Usia 2013. Retrieved from https:// bps.go.id/webside.pdf_publikasi / watermark_statistik penduduk lansia 2013.pdf

Badan Statistik Pusat. (2019). Statistik Indonesia Dalam Infograrif. Retrieved from Bps Statistic Indonesia

Bilotta, C., Bowling, A., Nicolini, P., Casè, A., Pina, G., Rossi, S. V., \& Vergani, C. (2011). Older People's Quality of Life (OPQOL) scores and adverse health outcomes at a one-year follow-up. A prospective cohort study on older outpatients living in the community in Italy. Health and Quality of Life Outcomes, 9, 1-10. https://doi.org/10.1186/14777525-9-72

Bowling, A., Hankins, M., Windle, G., Bilotta, C., \& Grant, R. (2013). A short measure of quality of life in older age: The performance of the brief Older People'sQuality of Life questionnaire (OPQOL-brief). Archives of 


\section{Gerontology.}

Bowling, Ann \& Liffe, S. (2011). Psychological approach to successful ageing predictts future quality of life in older adults. Health and Quality Of Life Outcomes, 9:13.

Bowling, A. E. al. (2012). A short measure of quality of life in older age: The performance of the breif older people's quality of life quesionnaire (OPQOL-brief). Arcchives of Gerontology and Geriatrics, 56(1), 181.

Browning, Colette \& Thomas, S. (2013). Enhancing quality of life in older people. Australian Psychological Sosiety.

Chalisen, H. . (2014). Depression among elderly in living in Briddashram (old age home). Advances in Aging Research, 3(1), 6-11. Retrieved from http://doi.org/10.1016/. ijge.2015.02.001

Gabriel, Z \& Bowling, A. (2004). Quality of life from the perspective of older people (online). Aging and Sosiety, 24 (05), 6.

Ita, D. S. (2017). Hubungan dukungan keluarga dengan kualitas hidup lansia yang menderita penyakit kronis di kota Medan. Jurnal Universitas Sumatra Utara.

Jennifer Reichstadt M.S, Geetika Sengupta M.D, Colin A Deep Ph.D, LawrenceA. Palinkas Ph.D, D. V. J. M. . (2010). Older Adults' Perspectives on Successful Aging: Qualitative Interviews. The American Journal of Geriatric Psychiatry, 18(7), 567-575. https://doi.org/10.1097/ JGP.0b013e3181e040bb

Kartinah \& Sudaryanto, A. (2008). Masalah psikososial pada lanjut usia. Jurnal Keperawatan Universitas Muhamadyah Semarang. Retrieved from http:// publikasiilmiah.ums.ac.id/biststream/ handle/11617/486/2h.pdf?

Kimm, Heejin. Jae woong sull, et all. (2012). Life statification and mortality in elderly people: the kangwha cohort study. BMC
Public Health.

Lei, X., Hu, Y., Mcardle, J. J., Smith, J. P. dan Zhao, Y. (2011). Gender Differences in Cognition among Older Adults in China. RAND Labor and Population, 1-33.

Li, C.-I. (2014). Successful aging defined by healthrelated quality of life and its determinants in community- dwelling elders. BMC Public Health Taiwan.

McCabe,M.P.,\&O'Connor,E.J.(2013).Alongitudinal study of quality of life among people living with a progressive neurological illness. Health, 05(06), 17-23. https://doi. org/10.4236/health.2013.56a2004

Netuveli, Gopalakrishnan \& Blane, D. (2008). Quality of life in older ages. Deprtemen of Primare Care and Social Medicine, Imperial College, London, UK.

Noorkasiani, T. \&. (2009). Kesehatan usia lanjut dengan pendekatan asuhan keperawatan. Jakarta: Salemba Medika.

Oh, S. H., Kim, D. K., Lee, S. U., Jung, S. H., \& Lee, S. Y. (2017). Association between exercise type and quality of life in a community-dwelling older people: A cross-sectional study. PloS One, 12(12), e0.

Putra, I. (2009). Perbandingan kualitas hidup lansia di panti sosial tresna werdha dengan lansia di keluarga. Jurnal Keperawatan: JOM PSIK, VOL1 No2.

Putri, Suci Tuty, N. (2013). STUDI KOMPARATIF : KUALITAS HIDUP LANSIA YANG TINGGAL BERSAMA KELUARGA DAN PANTI. Journal of Chemical Information and Modeling, 53(9), 1689-1699. https://doi. org/10.1017/CB09781107415324.004

Raras Anggun Atika Candra, Eva Rahayu, M. S. (2018). SUCCESSFUL AGING PADA LANSIA WANITA DI DESA RELATIONSHIP BETWEEN SELF WITH ACHIEVEMENT OF SUCCESSFULAGINGINELDERLYWOMENIN THE VILLAGE KARANGTENGAH Mahasiswa 
, 2, 3 Dosen Jurusan Keperawatan Fakultas Ilmu-Ilmu Kesehatan PENDAHULUAN Jumlah penduduk la. 15-30.

Reker, G. T., \& Wong, P. T. P. (1985). Personal optimism, physical and mental health: The triumph of successful aging. In J. E. Birren and J. Livingston (Eds.), Cognition, stress, and aging. Englewood Cliffs, NJ: PrenticeHall., 134-173.

Reker, G. T., \& Wong, P. T. P. (1997). Successful aging. The Gerontologist, 37, 433-44.

Rowe, J. W., \& Kahn, R. L. (1997). successful aging. The Gerontologist, 37, 433-44.

Ryff, C. D. (1989). Beyond Ponce de Leon and life satisfaction: New directions in quest of successful ageing. International Journal of Behavioral Development, 12, 35-55.

Tanaka, N. et al. (2013). Clinical utility of the Functional Independence Measure for assessment of patients with Alzheimer ' $s$ disease and vascular dementia. Gerontology, 199-205.

Veronica. (2017). Identifikasisuccessful agingpada lansia yang tinggaldi pesisir pantai kecamatan abelikota kendari. Politeknik Kesehatan Kendarijurusan Keperawatan.

Whitbourne, S. . (2005). Successful aging: Introductory perspectives. Research in Human Development, 2(3), 99-1. 
